\title{
Influence Of Country Culture On Bankruptcy And Insolvency Legal Reform Management
}

Enoch K. Beraho, South Carolina State University, USA Richard Elisu, South Carolina State University, USA

\begin{abstract}
Different countries employ different bankruptcy and insolvency approaches when trying to solve their economic problems. The purpose of this paper is to study the influence country culture and legal systems have on bankruptcy management in different countries. Bankruptcy data and information pertaining to legal practices of different countries were obtained from those countries' websites and various published documents. The data were examined and compared, noting differences in legal structures among the countries studied. It was found that, whereas the aim of bankruptcy laws was to remedy the countries' economic problems, the approaches taken differed markedly. In many cases, it was difficult to access bankruptcy data mainly because such data were published on Internet and no other reliable documents were available. To the author's knowledge, it seems very little specific work, if any, has been done in the areas relating to country cultural values, bankruptcy practices and management. In that sense this study is warranted. Furthermore, effective bankruptcy management across nations may benefit from this exposure, leading to more realistic reforms across the globe.
\end{abstract}

Keywords: Culture and legal systems; bankruptcy; insolvency; debt management

\section{INTRODUCTION}

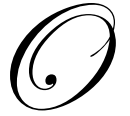

ver the last decade, the world has experienced economic difficulties, but some countries experienced more financial stress than others. In response to these economic hardships, most countries responded by reforming their legal systems to cope with their domestic financial problems. Even countries like China, which had socialist practices, began to reform their legal systems to allow market forces to play out in order to gain confidence of foreign investors (Eisebach, 2007; Dobbs, et al, 2004). The US, Canadian and British systems are much more detailed and expansive than those of Eastern Europe, China, S. Korea and Malaysia (InterNet BL, 2007; Chung, 2007; Zhou, 2006). Different countries emphasize different bankruptcy practices, consistent with their social and legal systems. The extent of those practices seems to be related to the stage of development of those systems.

What is apparent is that no system is static. There are changes in virtually all countries, although different counties have initiated more changes than others. The differences in reform approaches are expected because of the historical differences among the regions of the world. To highlight the pace of reforms in different countries, a few major countries were selected to exemplify regional differences, in general, and national trends in particular. The countries chosen represent different economic and political structures. Martin (2005) studied the reasons why so many nations have hastened the pace of bankruptcy law reforms in their respective countries. The author found that there is always some kind of economic crisis. Following that realization, countries ask themselves whether or not current legal systems can adequately handle the increase in corporate and bank failures. Failure does not have to occur before reform is called for. Credible indication that the national economy is in trouble or would soon be in trouble is enough to trigger movement toward reform. 


\section{Beginnings of Bankruptcy Law}

Although the Romans and the English are credited with origination and evolution of the bankruptcy legal systems, it seems that the notion of bankruptcy predates even the Roman bankruptcy procedures. If the Bible is looked at as a legitimate compilation of historical events, it becomes the earliest document on bankruptcy as a management tool to control the economy and allow citizens and businesses to avoid financial catastrophe and have a new beginning. In the book of Deuteronomy, Chapter 15, Verses 1-2, it is written that Moses brought home God's law from the mountain of the burning bush to the Israelites and counseled them to forgive debts every seven years. Moses counsel was "At the end of every seven years, thou shalt make a release (legalhelpers.com). Amazingly, Moses also describes a system of redemption after foreclosure that is very similar to those in effect today (bankruptcyrep.com).

Bankruptcy contemplates the "forgiveness" of debt. The Bible, likewise, contains debt forgiveness laws. Under U.S. law, a debtor may only receive a discharge of debts in a Chapter 7 bankruptcy once every eight (8) years. Under Biblical law, the release of debts came at the end of seven (7) years as stated below (legalhelpers.com; Tozer and Lofstedt, 2007):

"At the end of every seven years, you shall grant a release of debts. And this is the form of the release: Every creditor who has lent anything to his neighbor shall release it; he shall not require it of his neighbor or his brother, because it is called the LORD's release" (Deuteronomy 15:1-2).

The Bible refers to debt as a type of bondage: "...the borrower is a slave to the lender" (Proverbs 22:7). Thus, the debtor is a slave to the creditor. Interestingly, the Bible declares at the end of the sixth year:

"...in the seventh year, you shall let [your Hebrew slave] go free from you. And when you send him away free from you, you shall not let him go away empty-handed; but you shall supply him liberally from your flock..." (Deuteronomy 15:12-14).

Modern bankruptcy laws, like the Biblical provision above, allow debtors to keep certain property when they file bankruptcy. This gives debtors a fresh start and discourages debtors from going into debt-bondage again, after the bankruptcy is over, in order to survive (Tozer and Lofstedt). Bankruptcy has been around for over two thousand years. After Moses' bankruptcy command, the Romans created the first written history on the subject. In ancient Rome or Italy (later), money lenders conducted their trade from benches set up in town squares. Ancient records show that any merchant who failed to pay another merchant had his bench broken, sometimes over his head. This practice was meant to put the merchants out of misery of owing debt, by just forcing them out of business. The custom of breaking the bench became prevalent and insolvency became associated with a broken bench, (banca rotta, in Italian, eventually became bankrott in German, banqueroute, in French, and bankrupt in English). Later, during the Middle Ages, the incidence of bankruptcies increased and prompted the need for an organized bankruptcy procedure.

The word "bankruptcy" is believed to have originated from ancient Latin verbiage describing a "broken bench." Bancus, a tradesman's counter, and ruptus, meant broken or rotten, denoting one whose place of business was broken or gone. In medieval Italy, banca rotta evolved from the Roman equivalent of bancus ruptus. Other sources say that the practice of breaking the bench of the bankrupt was still practiced in Italy between the $9^{\text {th }}$ and $14^{\text {th }}$ centuries. During that period, whenever a man did not pay his debts, it was assumed that he refused. His credotors, were then allowed, by law, to go into his house or workplace and destroy his workbench, which meant the end of that debt. The expressions banca rotta or bancus ruptus were combined to become "bankruptcy" as we know it today.

Roman law provided for the sequestration (mission in bona) of a debtor's estate to be sold to satisfy a creditors' unpaid judgment (venditio bonorum). When proceedings of this type caused loss of civil rights, the law was amended to allow a debtor some privilege of voluntarily relinquishing assets to creditors by petitioning a magistrate (cessio bonorum). Essentially the Roman law set stage for balancing interests of the debtors and the creditors in the interest of the economic health of the nation. Behind this central idea was enactment of legislation to 
provide procedures for the adjustment of debts in order to avoid liquidation and for the rehabilitation of insolvent debtors, but past bankruptcy was coupled with the loss of civil rights and imposition of penalties upon fraudulent debtors. For that reason, the designation "bankrupt" came to be associated with dishonesty and thus casting a stigma on persons who were declared bankrupts.

The First definitive "bankruptcy laws" were established in England during the 16th Century. Back then, bankruptcy was considered a criminal offense. Even today in England, the bankruptcy laws are strict and debtors are not left with much for their own after declaring bankruptcy. Loss of job, divorce, unforeseen medical problems, or the rocket launch of interest rates on credit cards or loans could leave English debtors in a bad spot (legalhelpers.com). Modern bankruptcy laws have been formed from modification of several historical strands (britanica.com). Arising from those nascent legal frameworks of the past are the world's diverse bankruptcy systems practiced today. Modern bankruptcy laws are centered around preventive composition, arrangements, or corporate reorganizations. Some legal systems distinguish between insolvency and bankruptcy and others don't even mention insolvency. In the latter systems, all problems relevant to failure to pay debt are dealt with under bankruptcy. In general, though, insolvency indicates the inability to meet debts, while bankruptcy, on the other hand, results from a legal adjudication that the debtor has filed a petition or that creditors have filed a petition against the debtor. In the US, there have been several amendments to the bankruptcy code that is enshrined in the constitution under uniform laws.

Continual amendments to the bankruptcy laws have led to a number of different bankruptcy legal systems that have evolved independently from the past, but a common thread runs through all of them. The legislations are meant to salvage an enterprise in financial difficulty and give it an opportunity to remain viable and maintain employment opportunities and protect members of the labor force. So, it can be said that different bankruptcy law systems are different approaches meant to accomplish the same purpose; that is, to help the economy by protecting businesses and individuals from suffering debilitating financial hardships. The enterprise, or an individual, is allowed a chance to start over without being burdened with debt of the past.

\section{What Comes First: Culture or Law?}

Many scholars have debated the issue of whether culture shapes law or the other way around. One of the authors who has written comprehensively on evolution of bankruptcy law is Martin (2005). The author noted that throughout history, culture has taken the leading role through changing norms. Successive societal values also are responsible for the changes that evolve in the law. These changes specify what laws are necessary and appropriate in that period and country. That is why major changes in economic and political changes inspire legal reforms, too. From this understanding, it is not surprising that different countries reform their legal systems at different rates and varying intensity.

\section{OBJECTIVES OF THE STUDY}

The following are the objectives of this study:

1. To study trends in bankruptcy reform laws worldwide

2. To study types and rates of change across different legal and social systems worldwide.

\section{METHODOLOGY}

Data for study was obtained from the U.S. Bureau of Census, US Department of Commerce, US Department of Labor and the US Bankruptcy Courts records pertaining to USA in general. Reform information about other countries was obtained from those countries' government websites and various Internet search engines. So, basically, data and any other pertinent qualitative and quantitative data were obtained directly from relevant government agencies of the countries studied, published sources and the Internet. To illustrate the notion that bankruptcy practices are shaped by the culture of each nation, we will review some practices of a few major representative countries chosen from the West, East and the Pacific region. The countries chosen exhibit diversity in 
terms of political and economic systems. The countries are: US, UK, China, Ukraine and Malaysia, which represent different economic and legal systems, but they have been pursuing bankruptcy reforms in response to their economic problems.

Many authors believe that bankruptcies are on the increase in the US because of American corporate greed (Dobbs, 12/04). According to Dobbs of CNN News, greedy corporations are exporting American jobs overseas, thus contributing to unemployment and financial hardships in the USA. Observers, who hold views similar to Dobbs', claim that US corporations only care for profits and not for the welfare of their people. Most major corporations have established manufacturing plants in cheap labor countries like Mexico, China, S. Korea and Malaysia. For example, HP has outsourced its sales representative to India. Indeed, today it is difficult to find goods made in USA. Brazil, China and India are some of the countries of choice when it comes to banking, technology, financial services and manufacturing operations for US companies, but then bankruptcies are on the upward trend, even in countries where US outsources operations. Furthermore, it should be noted that even communist or socialist countries, like the Ukraine, China and Russia, are experiencing a surge in bankruptcies or insolvencies, as they are called in European countries (China Law Blog, 10/2006; Biryukov, 2004). Significant deterioration in a country's economy and surges in bankruptcy filings usually trigger legal reforms in those countries.

The U.S. bankruptcy system was brought about by the country's capitalist system which rewards entrepreneurialism backed by great consumer spending. It seems reasonable that such a system should incorporate a forgiving bankruptcy system in order to encourage and sustain high consumer spending. The same forgiving bankruptcy system would allow business reorganization and encourage risk taking and economic growth. Forgiving bankrupt individuals and businesses keeps capitalism alive and able to renew itself over time, and the concept of a new start is central to proper functioning of any meaningful bankruptcy system (Martin). Bankrupt individuals and businesses would worry less if they knew that if they fall in financial problems, they would not be obliterated from the economic map, but would have a chance to start all again or reorganize and survive the financial catastrophe (Braucher, 2006). Actually, bankruptcy may not be all that bad. This view is supported by Matur (January, 2007) who cited research that found that one of the best ways to encourage people to start businesses is to have lenient bankruptcy laws.

Table 1: Annual Business and Non-business Filings by Year (1980-2008)

\begin{tabular}{|c|c|c|c|c|}
\hline Year & $\begin{array}{c}\text { Totals } \\
\text { Filings }\end{array}$ & $\begin{array}{l}\text { Business } \\
\text { Filings }\end{array}$ & $\begin{array}{l}\text { Non-Business } \\
\text { Filings }\end{array}$ & $\begin{array}{c}\text { Consumer Filings } \\
\text { as a Percentage } \\
\text { of Total Filings }\end{array}$ \\
\hline 2000 & $1,253,444$ & 35,472 & $1,217,972$ & $97.17 \%$ \\
\hline 2001 & $1,492,129$ & 40,099 & $1,452,030$ & $97.31 \%$ \\
\hline 2002 & $1,577,651$ & 38,540 & $1,539,111$ & $97.56 \%$ \\
\hline 2003 & $1,660,245$ & 35,037 & $1,625,208$ & $97.89 \%$ \\
\hline 2004 & $1,1,597,462$ & 34,317 & $1,563,145$ & $97.85 \%$ \\
\hline 2005 & $2,078,415$ & 39,201 & $2,039,214$ & $98.11 \%$ \\
\hline 2006 & 617,660 & 19,695 & 597,965 & $96.81 \%$ \\
\hline 2007 & 850,912 & 28,322 & 822,590 & $96.67 \%$ \\
\hline 2008 & $1,117,771$ & 43,546 & $1,074,225$ & $96.10 \%$ \\
\hline
\end{tabular}

Source. American Bankruptcy Institute and bankruptcyaction.com. July 26, 2009

In pursuit of its capitalist ideals, the USA has done more than any other country in reforming and implementing Bankruptcy Laws. A new bankruptcy reform law was enacted in 2004 and took effect on October $17^{\text {th }}$, 2005. After its implementation, bankruptcy filing trends reversed course immediately, beginning with November 2005. Total annual filings have been much lower ever since. Table 1 shows total business and non-business bankruptcy filings from 2000 to 2008 . The table clearly exhibits data obtained before and after the Bankruptcy Law Reform was implemented. The table also shows that, although there was a steady increase in bankruptcy filings in 
the years preceding implementation of the new law, there was a sudden surge in filings in 2005. This surge is explained by examination of monthly filing statistics (not shown here) which show that most of the surge was recorded in September and the first two weeks of October 2005 as filers rushed to beat the October $17^{\mathrm{th}}, 2005$ deadline (American Bankruptcy Institute, 2006).

Table 1 shows that, in general, filings had an upward trend for all the years up to 2005, the year when a total of 2,078,415 cases were filled and the new reform law was implemented. This number is composed of 39,201 business and 2,039,214 non-business case filings. After that, they went substantially down, beginning with the year 2006 because the new bankruptcy law made it harder for some people to file. At the end of 2006, only a total of 617,660 combined cases were filed. This number represents just $29.7 \%$ of the number filed during 2005 when the new law took effect.

\section{The US Bankruptcy Reform Law of 2005}

The actual mechanism and the detailed implementation process of the new law are represented by Figure 1. This law has been described as the new harsher bankruptcy law. In fact, the new US bankruptcy law of 2005 clearly favors credit issuers and mortgage lenders.

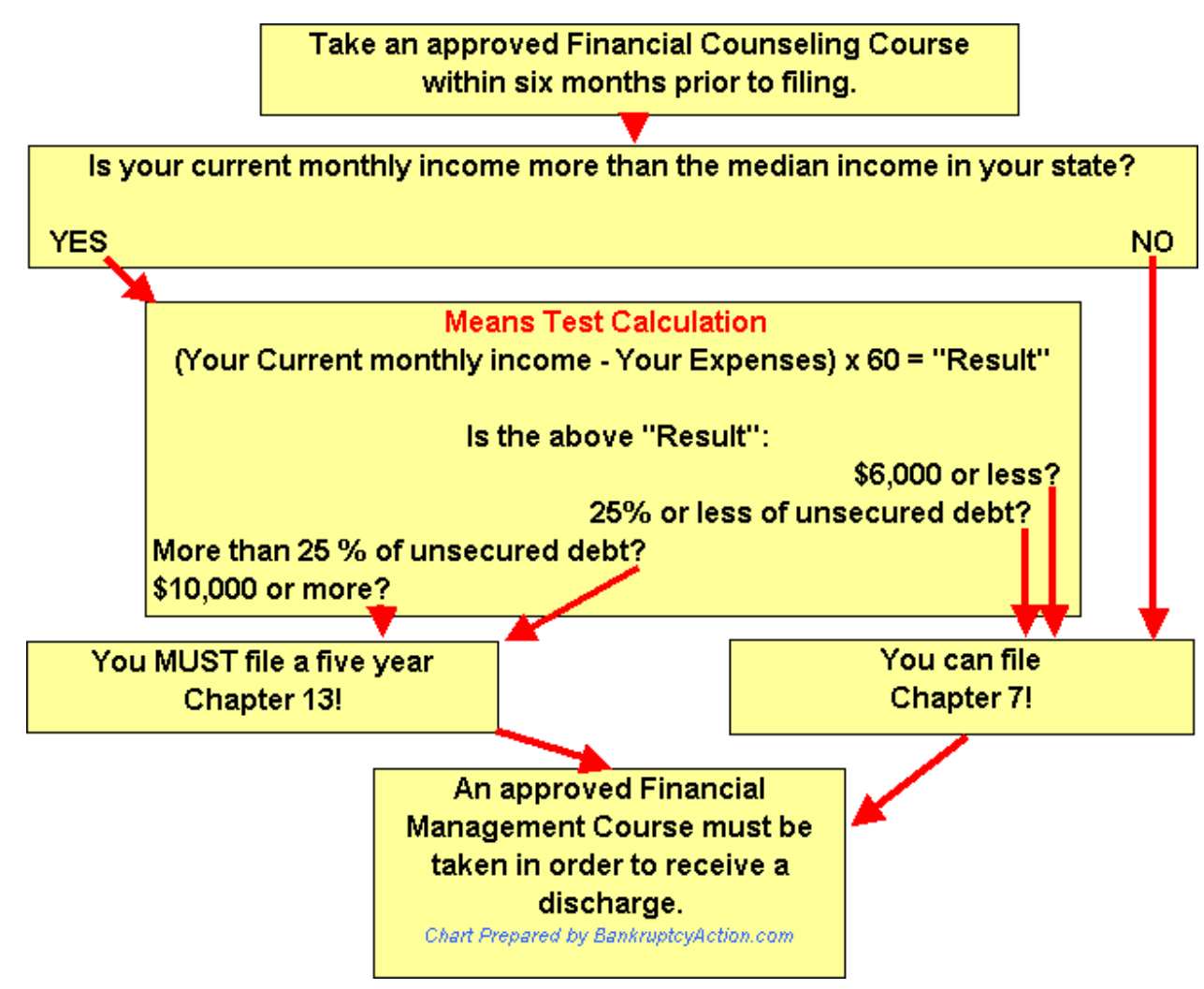

Figure 1: The New US Bankruptcy Law Flow Chat, 2005

Source. The New Bankruptcy Reform Act of 2005. This Flow Chart was prepared by BankruptcyAction.com

\section{The Five Big Changes}

Although there are many changes, bankruptcy remains a federal court process started by filing a petition. It is administered by a trustee, whom debtors meet at a meeting of creditors pursuant to Code Section 341 . The following are the five major revisions summarized by Fig. 1. (Doney and Associates, 2001; McCartney, 2003) 
1. A pre-filing Credit Counseling is required of all potential filers.

Under this new requirement, individual creditors must attend a counseling session and obtain a certificate to accompany a petition for any chapter relief.

2. Establishing a Needs Test Based Bankruptcy (Figure 1)

The new law critically examines the needs a filer has. The need assessment is based on the median income of the filer's state. If the filer's income is below the mean income of the state the filer lives in, the judge allows the debtor to file for bankruptcy. The type of bankruptcy will depend on the filer's financial situation. If a filer's disposable income is greater than that of his or her state, the debtor must work out a plan to repay.

3. Discouraging Repeat Cases

A debtor who previously filed for bankruptcy is not allowed to file again until 8 years have passed in Chapter 7 cases or 5 years in Chapter 13 cases.

4. Paying More in Chapter 13

If a debtor's income for the 6 months preceding the filing of bankruptcy is greater than the median income in the state, a 5-year Chapter 13 repayment plan must be worked out. Amount of plan payments is based on Internal Revenue Service's allowances and other allowances. Deduction of expenses is determined in accordance with the Means Test.

\section{Additional Rights of Secured Creditors}

Automatic stay provision, which stops creditors while the case is pending, is terminated if debt is not reaffirmed. Reaffirmation is in the form of a debtor filing and performing under a statement of intention.

\section{Trends in Global bankruptcy Reforms}

Bankruptcy filings are not limited to the U. S. A, although the US has engineered comprehensive reform which is viewed by some researchers as radical. During the period the US was reforming its laws, some European countries were also actively reviewing their respective filing trends which, in most cases, were increasing sharply. Consequently, most European countries implemented some reforms. Even some socialist countries namely China, Russia, the Ukraine, and other countries, which were known to be pro-workers and against capitalism, reformed their bankruptcy laws to favor businesses a lot more than before. However, their reforms were slow and limited in comparison to the US's sweeping changes in favor of credit issuers, mortgage lenders and other personal loan providers. Inclination of the US Congress to favor big businesses was inspired by heavy, relentless and expensive lobbying mounted by those financial institutions.

\section{Effects of Country Culture on Bankruptcy Perception}

It also appears that the propensity to file is influenced by the economic culture of a country. In the US, citizens are less likely to exercise restraint if it becomes apparent that they are financially hard up. Varona (July 2007) reported that the concept of consumer bankruptcy and "fresh start" is new in Europe. Demark spearheaded it in 1984. In France and Malaysia, the law focuses on the consumers' indebtedness rather than their insolvency. In all the countries studied, it was noted that reforms were not limited to domestic insolvencies. In fact, most European countries and the US are using the newly reformed Chapter 15 provision of the new law, which addresses across boarder insolvency to revolve international bankruptcy situations. Spain is viewed as different from other European countries. Varona (9/07) says that there is no consumer bankruptcy provisions in Spain's insolvency laws which were enacted in 2003. 
The European Union is highly rated for its consumer protection against credit market. Varona said that the Spanish are reluctant to file, while that is not the case in the US. In fact, Kilborn said that many scholars (arguably) referred to Americans as shameless when it comes to filing for bankruptcy, but he found examples in Japan and other countries that showed that the US is not alone when it comes to greed, although those other countries are still behind the US in the index of individuals or a business propensity to file for bankruptcy. It is thought that many Americans file for bankruptcy even when they could put off filing (creditslips.com). This attitude may have come about as a result of less stigma being associated with bankruptcy. It is possible that filers do not have stress over filing because they see the law overly favoring businesses and creditors. It has been noted, too, that no reforms can contain all bankruptcy filings. According to Kilborn (9/07), as soon as European states adopted laws that offer relief to insolvent individuals, another group arose. This is the group of individuals who are so broke that they cannot even pay a filing fee. They are known as "Nina debtors". They have no income and assets for creditors to take.

\section{Bankruptcy Reforms in England and Wales}

Bankruptcies in England and Wales showed a steady increase per quarter for the years 2005 and 2006. Bankruptcy statistics are organized in two categories:

1. Company Liquidation which is comprised of compulsory and creditor or voluntary based

2. Individual filings, which fall under either bankruptcies or Individual Voluntary Arrangements (IVAs)

\section{Bankruptcy and Insolvency Reform in Scotland}

Scottish law recognizes that it is very important to have fair solutions for individuals suffering from severe debt problems. For example, the debt arrangement scheme empowers individuals to deal with their own multiple debt problems with practical support.There are two main personal insolvency regimes in the UK: one for England and Wales and another for Scotland. In England and Wales, the majority of personal insolvencies are "bankruptcies". The remainder are Individual Voluntary Arrangements or IVAs, which are arrangements between the debtor and his or her creditors for the payment of the debts on different terms; for example, by installments or over a period of time. These two forms of insolvency have close equivalents in Scotland, where bankruptcies are known as sequestrations, which equivalent to IVAs are Protected Trust Deeds, or PTDs.

\section{Bankruptcy Reform in Malaysia}

The Malaysian Bankruptcy Act 1967 was amended in the year 2003 (Asnawi, 2007) and came into force on 1 October 2003. Essential changes the law brought can be found at: (e-Insolvency, 2005; www.myeg.com; www.rilek.com.my).

Some of changes brought about by the new amendment include (Indriani, 2005; Malaysia Today, 2005):

- $\quad$ A change in the title of the Official Assignee Malaysia to the Director-General Insolvency Malaysia (DGI).

- A requirement for a petitioning creditor to prove to the Court that he or she had exhausted all avenues to recover debts owed to him or her by the debtor before he or she can commence any bankruptcy action against a 'social guarantor'.

- An increase in the minimum debt, which enables a person to be declared bankrupt from RM10,000 to RM30,000.

- $\quad$ Stopping the calculation of the rate of interest on the date of the receiving order granted by the court in cases where the interest is not reserved or agreed upon.

- Conferring powers of a Commissioner of Police to the DGI and the powers of a police officer on the investigation officers to facilitate investigation, prosecution and enforcement.

\section{Personal Insolvency Procedures in Malaysia}

The personal insolvency procedures that apply in Malaysia are contained in the Bankruptcy Act 1967. A debtor can become bankrupt through either a debtor's petition or a creditor's petition. There is a summary 
administration available for small bankruptcies. A debtor can also avail himself/herself of a composition (mutual agreement or settlement) as an alternative scheme to bankruptcy. The Official Assignee administers all personal insolvency administrations Corporate Insolvency Procedures

The following insolvency procedures are available under the Companies Act of 1965:

- $\quad$ Pt 7 Arrangements and Reconstructions

- $\quad$ Pt 8 Receivers and Managers

- $\quad$ Pt 10 Winding Up

Winding-up can be a court procedure or a voluntary procedures (under the control of members for a solvent company or under the control of creditors for an insolvent company). Private practitioners can be appointed by, in windings-up, for instance, the Official Receiver can act as a liquidator and is a default liquidator if no other liquidator is acting.

\section{Role played by the Court}

The general powers of the Court in Bankruptcy are included in s91 of the Bankruptcy Act 1967. The Court has a general oversight role in relation to corporate insolvency procedures, especially where the court has appointed a liquidator.

\section{Ukraine's New Bankruptcy Reform Law Reviewed}

The first Ukraine law in recent history to regulate the property problems of financially distressed enterprises, the Bankruptcy Law, was adopted in 1992 (Biryakov, 2000). Enactment of the law was made necessary by an increase in insolvencies nationwide. Although the new law of 1999 contains a number of provisions that are broadly similar to those in the old law, as a whole it is constructed on completely different foundations. Much current international thinking was incorporated into the conceptual aspects of the new law. For example, the principle that legislation should protect not only creditors' interests, but also those of debtors, is reflected in the preamble to the law. The law also emphasizes that its main purpose is to restore the solvency of the debtor, and that only after measures to that end have failed will the debtor be declared bankrupt for the purposes of complete or partial satisfaction of the claims of the creditors.

The new law expands the range of persons that can be recognized as 'bankrupt'. It now includes consumer cooperatives, and charitable organizations and other funds. Bankruptcy proceedings can also be initiated against individuals, but only those who are registered as entrepreneurs. (An 'entrepreneur' is anyone recognized as such by the Law of Ukraine on Entrepreneurship of 1991. The new bankruptcy law also sets out a number of exceptions to the general rules on who can be declared bankrupt. 'State-owned enterprises with special status' (kazenni pidpryemstva) are one such group.

\section{Chinese and Vietnamese Bankruptcy Reform, 2007}

For China's program of economic reform, which sees the country opening its doors to the outside world, its newly passed bankruptcy law has twofold significance: to boost its credit market as it gives full access to foreign lenders, and to deal a final blow to the "iron rice bowl" employment system at its State-Owned Enterprises (SOEs) (Zhou, 2007; Eisenbach, 2007.) Following its commitment to accession to the World Trade Organization (WTO), China opened its banking sector to foreign lenders, which will then compete with their Chinese rivals on an equal footing. This will no doubt boost the development of China's credit market. But such development requires a legal basis, and that is where the new bankruptcy law comes into play. The law, which became effective on June 1, 2007, gives creditors' claims top priority when the debtors undertake the process of liquidation, which is more in line with the international practice. This would certainly give foreign banks some legal assurance when issuing yuan loans, particularly to SOEs (InterNet Bankruptcy Library 'IBL'), 1986. Executives of domestic lenders, particularly the four big state-owned banks - the Industrial and Commercial Bank of China, Bank of China, China Construction Bank and the Agricultural Bank of China - will also applaud the new law. The banks have had to dispatch "policy loans" on government orders to SOEs, and they suffer badly when their debtors become bankrupt. 
A good bankruptcy law can establish effective market constraints, push enterprises to improve governance, and stick to the principle of paying off obligations, as well as protecting the creditors' and debtors' rights. Nowadays in China, most of the collateral creditors are banks. Because the banks' claims are given a low priority, they became excessively cautious in lending, resulting in a credit crunch on mid-sized and small enterprises. From this viewpoint, the new bankruptcy law is expected to help boost China's credit market. In this sense, it will also likely help foster the social value of respecting credit, which is lacking in traditional Chinese culture. The new law will apply to all sorts of companies, including listed and non-listed companies, domestic and foreign companies, privately run or state-owned, as well as financial institutions.

The law epitomizes the gradual nature of China's market-oriented economic reform, which has largely centered on figuring out a viable way to close down insolvent SOEs. In theory, the current bankruptcy law also acknowledges that claims in liquidation should be given priority. In practice, however, the priority has in effect been subordinated by the so-called "policy bankruptcy", or bankruptcy ordered and administered by the government, which trumps the protection of creditors. Under current law, courts must get permits from the government before triggering the bankruptcy process. The new law ushers in the professional "bankruptcy manager" system in line with international business practice. Some analysts liken the reorganization practice to that under Chapter 11 of United States Bankruptcy Code (China Blog, 10/2006). Nevertheless, the new law is still a compromise between implementing an international standard and concern over social unrest. The government has implemented the new law cautiously. It exempted from the new law, an additional 2,116 SOEs already lining up for "policy bankruptcy" to enjoy the "Last Supper" until the end of 2008. Under some "special circumstances", the priority will be given to workers' obligations. The "caveat" addresses the interests of marginalized people during the transition to a freemarket economy.

\section{DISCUSSION}

Following enactment of US reform laws, a number of scholars have attempted to forecast the effects that these harsher laws are going to have on the filing process and the quality of life of those who file or would file. One of the issues that has generated concern is whether it will stifle filing to the extent that some small businesses and individuals in financial stress will just give up because of failing to meet the higher bar the stringent guidelines of the new law established as minimum criteria. Of particular concern is the fact that the residual amount, of $\$ 100 \mathrm{a}$ month, the cut off point for a filer to work out a payment schedule is considered too small. That small amount forces the majority of bankrupts to schedule payments with the court and disqualify them from total bankruptcy that would forgive them some debt after liens and collaterals are satisfied.

Again, it is only the US, through its Congress, that made reforms that clearly favor big businesses. These severe reforms were inspired by heavy, relentless and expensive lobbying mounted by those financial institutions. No country, other than the US, has reformed laws to grant lobbyists' wishes. What the reforms do more of is favor loan lenders, mortgage lenders, and credit card issuers. It makes it very difficult for a debtor to be forgiven debt, except under extremely dire circumstances. So, poor people may still have to make arrangements to repay their debts even when they are living from hand to mouth.

In Malaysia, filing for bankruptcy is made harder by a high debt requirement. A major deference between US and Malaysia is that in the US, it is the indebtedness and ability to pay that defines the law, whereas in Malaysia, it is how much debt one has incurred that qualifies a debtor. That is the reason why recently, in Malaysia, the minimum debt to file has been raised from RM10,000 to RM 30,000 (about US $\$ 3,050$ to $\$ 9,250$ ). It means that debtors with less than US $\$ 9,250$ in debt cannot file for bankruptcy, even if they have no means to pay. The requirement for a minimum amount of debt to qualify for bankruptcy is unique to Malaysia. Not only that, the government has created an office of Inspector General of Insolvencies (IGI) and has given that position "police power" to arrest and prosecute violators.

The Ukrainian reforms now address international concerns and are directed toward helping the debtor become solvent. This new approach puts Ukrainian law in line with international legal thinking, but the law limits people who can be recognized as bankrupt. To qualify for bankruptcy, individuals must be registered as an entrepreneur. This is not the case with other countries studied. Also, the reformed law does not discriminate between 
resident and non-resident filers. This is a departure from the old law. Just like Ukraine did, China reformed its bankruptcy laws to allow non-residents to file and reassure foreign investors that they, too, can benefit from the new law. Furthermore, the new law treats workers and SOEs equally well. The old law leaned more towards the SOEs. The new law helps reduce the probability of worker revolt when they are laid off, cannot pay their bills, and are not allowed to file for bankruptcy. In that regard, the reforms help the workers and the SOEs to the extent that they qualify.

Everything considered, though, all the countries studied show that they reformed their laws to protect debtors and creditors, but they did so to varying extent. The US and Malaysian reforms protected creditors a lot more than they did debtors, while the Chinese reforms, although they do not go far enough, appear to treat creditors and debtors equally. The reforms are still evolving at different paces and intensity in different countries. The common catalyst for the observed changes in bankruptcy laws worldwide is the uncertainty of economic downturn being experienced globally.

\section{AUTHOR INFORMATION}

Dr. Enoch K. Beraho is Professor of Management in the Department of Business Administration, College of Business and Applied Professional Sciences, South Carolina State University, Orangeburg, SC, USA. The author conducts a USDA funded research project on bankruptcies in South Carolina. The author has published and presented articles, nationally and internationally, on bankruptcy in the USA and on Sub-Saharan Economic and Strategic Development in partnership with the US Congress's African Growth and Opportunity Act (AGOA).

Richard Elisu is a graduate student in the Department of Business Administration, College of Business and Applied Professional Sciences, South Carolina State University, Orangeburg, SC, USA. Elisu is a native of Uganda. The student works with Dr. Enoch Beraho on bankruptcy filings in South Carolina and is primarily responsible for statistical sampling, compilation and analysis of bankruptcy data from US courts.

\section{REFERENCES}

1. American Bankruptcy Institute and bankruptcyaction.com. July 26, 2006, http://www.abiworld.org/AM/AMTemplate.cfm?Section=Home\&CONTENTID=57826\&TEMPLATE=/C M/ContentDisplay.cfm.

2. Asnawi, H D. Department of Insolvency. The Malaysian Bankruptcy Act 1967. International Association of Insolvency Regulators (IAIR) 2007, www.bheuu.gov.my/jphwww.bheuu.gov.my/jph. www.myeg.com.my; www.e-service.com.my or www.rilek.com.my.

3. Bankrate.com. January, 2006.

4. BankruptcyAction.com. April 20 2005.

5. BankruptcyData.com, June $2003-2006$.

6. Bankruptcyrep.com.

7. Biryukov, Alexander. Kiev National University explains the origins, provisions and scope of the recentlyenacted insolvency legislation in Ukraine, and its importance to economic reform. http://www.ageyev.com/articles/biryukov/UkrainianBankruptcyReform.pdf.

8. Braucher, Jean, "A Fresh Start for Personal Bankruptcy Reform: The Need for Simplification and a Single Portal" . American University Law Review, Vol. 55, 2006. http://ssrn.com/abstract=912561.

9. $\quad$ China Law Blog, October 2006.

10. Chung, Olivia. Bankruptcy law to protect China investors. China Business, June 9, 2007. http://www.atimes.com/atimes/China_Business/IF09Cb01.html.

11. Dobbs, Lou and Joanne Myers. Exporting America: Why Corporate Greed Is Shipping American Jobs Overseas . CNNMoney, December 2, 2004.

12. Doney and Associates Law Firm PLC, 2006. http://www.doney.net/bra/DA_flowchart.gif.

13. e-Insolvency, 2005.

14. Eisenbach, Robert, L. English Translation Of China's New Enterprise Bankruptcy Law'; Global House Price Crash Forum (Kuala Lumpur, Malaysia, May 1, 2005). http://forum.globalhousepricecrash.com/index.php?showtopic=65. 
15. Indriani T. Malaysian bankruptcies surge by 47\% from 2001 Monday, May 02, 2005. Global House Price Crash Forum. http://forum.globalhousepricecrash.com/index.php?showtopic=65.

16. InterNet Bankruptcy Library (IBL). Law on Enterprise Bankruptcy - China. http://www.bankrupt.com/about_ibl.html, December 2, 1986.

17. International Association of Insolvency Regulators IAIR, 2007, Malaysia. http://www.insolvencyreg.org/sub_member_profiles/malaysia/index.htm.

18. The Law Offices of McCartney, P.C. http://www.bankruptcyrep.com/the_new_law_htm.

19. Legalhelpers.com.

20. Kilborn, Jason. Shameless Americans? www.credit slips.org, 9/30/07.

21. Malaysia Today May 2, 2005. Malaysian bankruptcies surge by $47 \%$ from 2001. http://www.malaysia-today.net/Blog-e/2005/05/malaysian-bankruptcies-surge-by-47.htm 2004. Malaysia Today www.malaysia-today.net.

22. Martin, Nathalie. Boston College International and Comparative Review Vol. 28, \#2, 2005. http://papers.ssrn.com/so13/papers.cfm?abstract id=1444531.

23. Mathur, Aparna. Forgive Us Our Debts . American.com, Online Magazine, January 8, 2007. http://www.american.com/search?SearchableText=forgive+us+our+debts \&x=9\&y=5.

24. McCartney, Ken. Law Offices P. C. The Rules Have Changed. http://www.bankruptcyrep.com/the new law.htm.

25. Myeg.com.

26. rilek.com.my.

27. Tozer and Lofstedt, 2007. Is bankruptcy spiritual: What does the bible say? http://www.christianattorney.net/bible_bankruptcy.html.

28. Zhou, Scott, 2006. Foreign credit racks China's 'iron rice bowl'. 2006 Asia Times Online Ltd. http://www.atimes.com/atimes/China_Business/HI02Cb02.html 
NOTES 